\title{
PENGARUH KUALITAS PELAYANAN, HARGA DAN FASILITAS TERHADAP KEPUASAN PELANGGAN PADA RUMAH SAKIT ISLAM NASHRUL UMMAH LAMONGAN
}

\author{
*(Ali Fathoni, Hery Suprapto \\ Fakultas Ekonomi \\ Universitas Islam Lamongan
}

\begin{abstract}
ABSTRAK
Penelitian ini mempunyai tujuan untuk mengetahui apakah kualitas pelayanan, harga dan fasilitas berpengaruh secara parsial maupun simultan terhadap pelanggan pada Rumah Sakita Islam I Nashrul Ummah Lamongan, serta untuk mengetahui faktor manakah yang paling dominan diantara ketiga faktor diatas yang mempengaruhi kepuasan pelanggan pada Rumah Sakita Islam Nashrul Ummah Lamongan. Maka diajukan hipotesis pertama diduga kualitas pelayanan, harga dan fasilitas berpengaruh secara parsial terhadap kepuasan pelanggan pada Rumah Sakita Islam Nashrul Ummah Lamongan, kedua diduga kualitas pelayanan, harga dan fasilitas berpengaruh secara simultan terhadap kepuasan pelanggan pada Rumah Sakita Islam Nashrul Ummah Lamongan, ketiga diduga kualitas pelayanan berpengaruh paling dominan terhadap kepuasan pelanggan pada Rumah Sakit Islam Nashrul Ummah Lamongan. Metode yang digunakan adalah metode kuantitatif dengan menggunakan uji validitas, uji reliabilitas, regresi linier berganda, korelasi berganda, koefisien determinasi, uji $t$ dan uji F. Hasil dari penelitian ini adalah: (1) Secara parsial kualitas pelayanan, harga dan fasilitas berpengaruh positif dan signifikan terhadap kepuasan pelanggan pada Rumah Sakita Islam Nashrul Ummah Lamongan. (2) Secara simultan kualitas pelayanan, harga dan fasilitas berpengaruh positif dan signifikan terhadap kepuasan pelanggan pada Rumah Sakita Islam Nashrul Ummah Lamongan. (3) variabel kualitas pelayanan yang paling dominan berpengaruh terhadap kepuasan pelanggan. Kesimpulan dari penelitian ini adalah variabel kualitas pelayanan, harga dan fasilitas berpengaruh terhadap kepuasan pelanggan pada Rumah Sakita Islam Nashrul Ummah Lamongan.
\end{abstract}

Kata Kunci : Kualitas Pelayanan, Harga, Fasilitas, Kepuasan Pelanggan.

\section{PENDAHULUAN}

Wyckof (dalam Fandy Tjiptono, 2004:260) kualitas jasa adalah tingkat keunggulan yang diharapkan dan pengendalian atas tingkat keunggulan tersebut untuk memenuhi keinginan pelanggan. Sedangkan menurut gunawan (2010:183) Jasa adalah setiap perbuatan ataupun kinerja yang dapat ditawarkan suatu pihak kepada pihak lain yang pada dasarnya bersifat tidak tampak (intangible) dan tidak mengakibatkan adanya perpindahan kepemilikan atas sesuatu. Proses produksinya bisa terikat pada sesuatu produk fisik.

Tjiptono (2004:57) kualitas merupakan suatu kondisi dinamis yang berpengaruh dengan produk, jasa, 
manusia, proses dan lingkungan yang memenuhi atau melebihi harapan. Sehingga definisi kualitas pelayanan dapat diartikan sebagai upaya pemenuhan kebutuhan dan keinginan pelanggan serta ketepatan penyampaiannya dalam mengimbangi harapan pelanggan.

Gunawan (2010:209) Harga jual produk adalah salah satu elemen dalam bauran pemasaran yang menghasilkan revenue penjualan, sedangkan elemen lain dari bauran itu menghasilkan biaya-biaya. Harga jual produk juga mampu mengkomunikasikan pada pasar tentang nilai positioning yang dimaksudkan oleh perusahaan atau brand-nya.

Tjiptono ( 2004 : 93) Fasilitas merupakan segala sesuatu yang mempermudah pasien dalam memperoleh manfaat dari jasa yang di berikan rumah sakit. Pada sejumlah tipe jasa, persepsi yang terbentuk dari interaksi antara pelanggan dengan fasilitas jasa berpengaruh signifikan terhadap kualitas jasa bersangkutan di mata pelanggan. Pasien juga akan merasa terlayani dengan baik sehingga dengan ketersediaan fasilitas yang baik dapat menimbulkan kepuasan pasien.

Howard \& Sheth (dalam Tjiptono, 2014:353) mengungkapkan bahwa kepuasan pelanggan adalah situasi kognitif pembeli berkenaan dengan kesepadanan atau ketidak sepadanan antara hasil yang didapatkan dibandingkan dengan pengorbanan yang dilakukan. Westbrook \& Reilly (dalam Tjiptono, 2014:353) mendefinisikan kepuasan pelanggan sebagai evaluasi secara sadar atau penilaian kognitif menyangkut apakah kinerja produk relatif bagus atau jelek atau apakah produk bersangkutan cocok atau tidak cocok dengan tujuan/pemakaiannya.
Rumusan masalah pada penelitian ini adalah: (1) Apakah kualitas pelayanan, harga dan fasilitas berpengaruh secara parsial terhadap pelanggan pada RSI Nashrul Ummah Lamongan? (2) Apakah kualitas pelayanan, harga dan fasilitas berpengaruh secara simultan terhadap pelanggan pada RSI Nashrul Ummah Lamongan? (3) Manakah diantara variabel kualitas pelayanan, harga dan fasilitas yang paling berpengaruh secara dominan terhadap pelanggan pada RSI Nashrul Ummah Lamongan?

Adapun tujuan dari penelitian ini adalah: (1) Untuk mengetahui apakah kualitas pelayanan, harga dan fasilitas berpengaruh secara parsial terhadap kepuasan pelanggan pada RSI Nashrul Ummah Lamongan. (2) Untuk mengetahui apakah kualitas pelayanan, harga dan fasilitas berpengaruh secara simultan terhadap kepuasan pelanggan pada RSI Nashrul Ummah Lamongan. (3) Untuk mengetahui manakah diantara variabel kualitas pelayanan, harga dan fasilitas yang paling berpengaruh secara dominan terhadap kepuasan pelanggan pada RSI Nashrul Ummah Lamongan.

\section{LANDASAN TEORI}

Pengertian Rumah Sakit, Rumah sakit merupakan sebuah tempat, tetapi juga sebuah organisasi. Pengertian yang paling klasik menyatakan bahwa rumah sakit adalah institusi atau fasilitas yang menyediakan pelayanan pasien rawat inap.

Rumah sakit adalah institusi atau fasilitas memberikan pelayanan kepada pasien berupa diagnostic dan terapeunik untuk berbagai penyakit dan masalah kesehatan, baik yang bersifat bedah maupun non bedah. Rumah sakit harus di bangun, dilengkapi dan di pelihara dengan baik untuk menjamin kesehatan dan keselamatan pasiennya dan harus 
menyediakan fasilitas yang lapang tidak berdesak-desakan dan terjamin sanitasinya bagi kesembuhan pasien. (American Hospital Association di tahun 1978).

Rumah sakit adalah suatu system kesehatan yang paling kompleks dan paling efektif di dunia ( Rowland \& Rowland dalam buku Hospital Administration Handbook 1984 )

Rumah sakit adalah institusi yang memberikan pelayanan kesehatan yang bersifat dasar, spesialistik dan subspesialistik. Rumah sakit mempunyai misi memberikan pelayanan kesehatan yang bermutu dan terjangkau oleh masyarakat dalam rangka meningkatkan derajat kesehatan masyarakat. Tugasnya adalah melakukan upaya kesehatan secara berdaya guna dan berhasil guna mengutamakan upaya penyembuhan dan pemulihan yang dilaksanakan secara serasi dan terpadu dengan upaya peningkatan dan pencegahan serta melaksanakan upaya rujukukan. Untuk itu rumah sakit harus benarbenar berfungsi dengan baik sesuai yang tercantum di dalam aturan diatas. ( SK Menteri Kesehatan RI No.983/Menkes?SK?XI1992 ).

\section{METODELOGI PENELITIAN}

Jenis penelitian yang digunakan adalah kuantitatif. Data kuantitatif adalah data berupa angka. Sesuai dengan bentuknya, data kuantitatif dapat diolah atau dianalisis dengan menggunakan teknik perhitungan statistik, (Syofian, 2013:17).

Uji Validitas adalah menunjukkan sejauh mana suatu alat ukur mampu mengukur apa yang ingin diukur (a valid measure if it succesfully measure the phenomenon). (Ir. Syofian, 2013:46)
Rumus:

$$
r_{\text {hitung }}=\frac{n\left(\sum X Y\right)-\left(\sum X\right)\left(\sum Y\right)}{\sqrt{\left[n\left(\sum X^{2}\right)-\left(\sum X\right)^{2}\right]\left[n\left(\sum Y^{2}\right)-\left(\sum Y\right)^{2}\right]}}
$$

Di mana:

$\mathrm{n}=$ Jumlah responden

$\mathrm{x}=$ Skor variabel (jawaban responden)

$\mathrm{Y}=$ Skor total dari variabel (jawaban responden)

Uji Reliabilitas adalah untuk mengetahui sejauh mana hasil pengukuran tetap konsisten, apabila dilakukan pengukuran dua kali atau lebih terhadap gejala yang sama dengan menggunakan alat pengukur yang sama pula. (Ir. Syofian, 2013:55).

Rumus:

Menentukan nilai varians setiap butir pertanyaan.

$$
\sigma_{i}^{2}=\frac{\sum X_{I}^{2}-\frac{\left(\sum X_{i}\right)^{2}}{n}}{n}
$$

Menentukan nilai varians total.

$$
\sigma_{t}^{2}=\frac{\sum X^{2}-\frac{\left(\sum x\right)^{2}}{n}}{n}
$$

Menentukan reliabilitas instrumen

$$
r_{11}=\left[\frac{k}{k-1}\right]\left[1-\frac{\sum \sigma_{b}^{2}}{\sigma_{t}^{2}}\right]
$$

Di mana:

$$
\begin{aligned}
& \mathrm{n} \quad=\text { Jumlah sampel } \\
& \mathrm{X}_{1}=\text { Jawaban responden } \\
& \text { untuk setiap butir } \\
& \text { pertanyaan } \\
& \sum \mathrm{X}=\text { Total jawaban } \\
& \text { responden untuk setiap } \\
& \text { butir pertanyaan }
\end{aligned}
$$

Regresi berganda adalah pengembangan dari regresi linier 
sederhana, yaitu sama-sama alat yang dapat digunakan untuk memprediksi permintaan di masa akan datang berdasarkan data masa lalu atau untuk mengetahui pengaruh satu atau lebih variabel bebas (independent) terhadap satu variabel tak bebas (dependent) (Ir. Syofian, 2013:301).

Rumus:

$$
\begin{aligned}
& \mathrm{Y}=\mathrm{a}+\mathrm{b}_{1} \mathrm{X}_{1}+\mathrm{b}_{2} \mathrm{X}_{2}+\mathrm{b}_{3} \mathrm{X}_{3} \ldots \\
& \quad+\mathrm{b}_{\mathrm{n}} \mathrm{X}_{\mathrm{n}}
\end{aligned}
$$

Analisis korelasi berganda adalah untuk mengetahui derajat atau kekuatan hubungan antara tiga variabel atau lebih, serta untuk mengetahui kontribusi yang diberikan secara simultan oleh variabel $\mathrm{X}_{1}$ dan $\mathrm{X}_{2}$ terhadap nilai variabel $\mathrm{Y}$ dan kontribusi secara parsial yang diberikan oleh variabel $\mathrm{X}_{1}$ terhadap $\mathrm{Y}$ serta $\mathrm{X}_{2}$ terhadap $\mathrm{Y}$. (Ir. Syofian, 2013:262).

\section{Rumus:}

$$
\begin{aligned}
& \mathrm{R}_{\mathrm{X} 1 . \mathrm{X} 2 . \mathrm{Y}} \\
& =\sqrt{\frac{r_{X 1 . Y}^{2}+r_{X 2 . Y}^{2}-2\left(r_{X 1 . Y}\right)\left(r_{X 2 . Y}\right)\left(r_{X 1 . X 2}\right)}{1-r_{X 1 . X 2}^{2}}} \\
& \text { Di mana: } \\
& \text { RX1.X2.Y = Koefisien korelasi } \\
& \text { ganda } \\
& \mathrm{X} 1=\text { Variabel bebas ke } 1 \\
& \mathrm{X} 2=\text { Variabel bebas ke } 2 \\
& \mathrm{Y} \quad=\text { Variabel tak bebas }
\end{aligned}
$$

Koefisien determinasi (KD) adalah angka yang menyatakan atau digunakan untuk mengetahui kontribusi atau sumbangan yang diberikan oleh sebuah variabel atau lebih X (bebas) terhadap variabel $\mathrm{Y}$ (terikat). (Ir. Syofian, 2013:252)
$\mathrm{KD}=(\mathrm{r}) 2 \times 100 \%$

Keterangan:

KD: koefisien determinasi

$r$ : korelasi berganda

Uji t, statistik ini berguna untuk membuktikan signifikan / tidaknya pengaruh variabel bebas terhadap variabel terikat secara individual dengan tingkat kepercayaan $95 \%$ dan tingkat kesalahan 5\% dengan rumus berikut (Sugiyono, 2013: 237)

$$
t=\frac{r(n-3)}{\sqrt{1-r^{2}}}
$$

Dimana :

$\mathrm{r}=$ koefisiensi korelasi

$\mathrm{n}=$ jumlah responden

$\mathrm{t}=\mathrm{uji}$ hipotesis

\section{HASIL PENELITIAN DAN PEMBAHASAN}

Tabel 1. Hasil uji validitas

\begin{tabular}{|l|c|c|c|}
\hline $\begin{array}{c}\text { Indikator } \\
\text { pertanyaan }\end{array}$ & $\mathbf{r}_{\text {hitung }}$ & $\mathbf{r}_{\text {tabel }}$ & keterangan \\
\hline $\begin{array}{l}\text { Kualitas } \\
\text { pelayanan }\end{array}$ & 0,591 & 0,582 & Valid \\
\hline Harga & 0,616 & 0,582 & Valid \\
\hline Fasilitas & 0,605 & 0,582 & Valid \\
\hline $\begin{array}{l}\text { Kepuasan } \\
\text { pelanggan }\end{array}$ & 0,592 & 0,582 & Valid \\
\hline
\end{tabular}

Sumber: data kuesioner diolah dengan SPSS

Dari tabel 1 dapat dilihat bahwa hasil uji validitas diperoleh dimana variabel Kualitas Pelayanan $\left(\mathrm{X}_{1}\right) \mathrm{r}_{\text {hitung }}$ $>\mathrm{r}_{\text {tabel }}$ yaitu $(0,591>0,582)$, Harga $\left(\mathrm{X}_{2}\right) \quad \mathrm{r}_{\text {hitung }}>\mathrm{r}_{\text {tabel }}$ yaitu $(0,616>$ 0,582), Fasilitas $\left(\mathrm{X}_{3}\right) \mathrm{r}_{\text {hitung }}>\mathrm{r}_{\text {tabel }}$ yaitu $(0,605>0,582)$, Kepuasan Pelanggan (Y) $\mathrm{r}_{\text {hitung }}>\mathrm{r}_{\text {tabel }}$ yaitu $(0,592>0,582)$, menunjukkan bahwa pada tingkat signifikan $\alpha=0,05$ dengan derajat bebas (df) tertentu, jumlah pertanyaan adalah 11 jadi $\mathrm{df}=$ $\mathrm{n}-\mathrm{k}-1=11-3-1=7$, maka $\mathrm{r}(0,05 ; 7)=$ 0,582 sehingga dapat dikatakan instrumen dalam variabel ini valid. 
Tabel 2. Koefisien Korelasi (r)

\begin{tabular}{|l|c|c|c|}
\hline $\begin{array}{c}\text { Indikator } \\
\text { pertanyaan }\end{array}$ & $\begin{array}{c}\text { Koefisien } \\
\text { Korelasi } \\
(\mathbf{r})\end{array}$ & $\begin{array}{c}\text { Nilai } \\
\text { kritis }\end{array}$ & $\begin{array}{c}\text { Keterang } \\
\text {-an }\end{array}$ \\
\hline $\begin{array}{l}\text { Kualitas } \\
\text { pelayanan }\end{array}$ & 0,777 & 0,6 & Reliabel \\
\hline Harga & 0,761 & 0,6 & Reliabel \\
\hline Fasilitas & 0,753 & 0,6 & Reliabel \\
\hline $\begin{array}{l}\text { Kepuasan } \\
\text { pelanggan }\end{array}$ & 0,757 & 0,6 & Reliabel \\
\hline
\end{tabular}

Sumber: data kuesioner diolah dengan SPSS

Dari tabel 2 dapat dilihat bahwa hasil pengujian reliabilitas dengan SPSS diperoleh koefisien alpha Kualitas pelayanan sebesar 0,777 , Harga sebesar 0,761, fasilitas sebesar 0,753 dan kepuasan pelanggan sebesar 0,757 . Koefisien alpha yang diperoleh dibandingkan dengan nilai kritis, jika lebih besar dari nilai kritis berarti instrumen reliabel. Pada taraf $\alpha=0,05$ dan $\mathrm{n}=100$ diperoleh ternyata koefisien alpha yang diperoleh masing- masing variabel adalah $>0,6$, yang artinya instrumen yang digunakan Reliabel.

Tabel 3. Hasil Regresi Linier Berganda

\begin{tabular}{|l|r|r|}
\hline Model & \multicolumn{1}{|l|}{ B } & \multicolumn{1}{l|}{ Beta } \\
\hline Konstanta & 4,777 & 1,101 \\
\hline $\mathrm{X}_{1}$ & 0,230 & 0,069 \\
\hline $\mathrm{X}_{2}$ & 0,197 & 0,111 \\
\hline $\mathrm{X}_{3}$ & 0,229 & 0,116 \\
\hline
\end{tabular}

Dari tabel 3 diperoleh persamaan:

$$
\mathrm{Y}=4,777+0,230 \mathrm{X} 1+0,197 \mathrm{X} 2
$$
$+0,229 \mathrm{X} 3$, yang diartikan sebagai berikut:

$\mathrm{a}=4,777$ merupakan intersep (constanta) yang berarti apabila variabel bebas dalam penelitian (kualitas pelayanan, harga dan fasilitas) pengaruhnya sama dengan nol maka hasil yang diperoleh dari kepuasan pelanggan adalah 4,777 $b_{1}=0,230$, artinya untuk variabel kualitas pelayanan koefisien regresi $\left(b_{1}\right)$ menunjukkan nilai 0,230 yang berarti apabila variabel kualitas pelayanan mengalami kenaikan satu unit maka akan dapat meningkatkan terhadap kepuasan pelanggan sebesar 0,230 pada saat variabel bebas yang lain sama dengan nol.

$\mathrm{b}_{2}=0,197$, artinya untuk variabel harga koefisien regresi $\left(b_{2}\right)$ menunjukkan nilai 0,197 yang berarti apabila variabel harga mengalami kenaikan satu unit maka akan dapat meningkatkan terhadap kepuasan pelanggan sebesar 0,197 pada saat variabel bebas yang lain sama dengan nol.

$b_{3}=0,229$, artinya untuk variabel fasilitas koefisien regresi (b3) menunjukkan nilai 0,229 yang berarti apabila variabel fasilitas mengalami kenaikan satu unit maka akan dapat meningkatkan terhadap kepuasan pelanggan sebesar 0,229 pada saat variabel bebas yang lain sama dengan nol.

Tabel 4. Koefisien Korelasi dan Koefisien Determinasi

\begin{tabular}{|c|l|c|}
\hline No. & \multicolumn{1}{|c|}{ Keterangan } & Nilai \\
\hline 1. & $\begin{array}{l}\text { Nilai Koefisien } \\
\text { Korelasi }\end{array}$ & 0,555 \\
\hline 2. & $\begin{array}{l}\text { Nilai Koefisien } \\
\text { Determinasi }\end{array}$ & 0,308 \\
\hline
\end{tabular}

Dari tabel 4 dapat dilihat bahwa nilai korelasi yang diperoleh yaitu sebesar 0,555 sehingga diketahui bahwa terdapat korelasi secara bersama-sama antara variabel kualitas pelayanan $\left(\mathrm{X}_{1}\right)$, harga $\left(\mathrm{X}_{2}\right)$, fasilitas $\left(\mathrm{X}_{3}\right)$ terhadap kepuasan pelanggan $(\mathrm{Y})$ sebesar 55,5\%. Korelasi dalam batasan ini yaitu korelasi antara ke semua variabel bebas terhadap variabel terikat (simultan) dan korelasi untuk masing-masing variabel bebas dengan tanpa menyertakan variabel bebas yang lain (parsial) terhadap variabel 
terikat. Sedangkan perhitungan SPSS diperoleh nilai koefisien determinasi secara simultan sebesar 0,308. Hal ini menunjukkan bahwa fluktuasi (tingkat gerakan) nilai variabel terikat (kepuasan pelanggan) yang disebabkan oleh variabel bebas yaitu kualitas pelayanan, harga dan fasilitas sebesar 30,8\%, Sedangkan sisanya $(100 \%-31 \%=69 \%)$ diterangkan oleh variabel lain yang tidak diteliti (Kehandalan, Ketanggapan, Keyakinan dan lain sebagainya)

Tabel 5. Hasil Perhitungan Uji t

\begin{tabular}{|c|c|c|c|c|}
\hline Model & $\mathrm{t}_{\text {hitung }}$ & $\mathrm{t}_{\text {tabel }}$ & Sig. & Keterangan \\
\hline Konstanta & 4,340 & 1,661 & 0,000 & \\
\hline $\mathrm{X}_{1}$ & 3,343 & 1,661 & 0,001 & Signifikan \\
\hline $\mathrm{X}_{2}$ & 1,772 & 1,661 & 0,079 & Signifikan \\
\hline $\mathrm{X}_{3}$ & 1.979 & 1,661 & 0,051 & Signifikan \\
\hline
\end{tabular}

Sumber: data kuesioner diolah

Dari tabel 5 dapat dilihat bahwa nilai variabel Kualitas Pelayanan $\left(\mathrm{X}_{1}\right)$ $t_{\text {hitung }}>t_{\text {tabel }}$ yaitu $(3,343>1,661)$ dengan tingkat signifikansi $0.001<$ 0,05 , Harga $\left(X_{2}\right) t_{\text {hitung }}>t_{\text {tabel }}$ yaitu $(1,772>1,661)$ dengan tingkat signifikansi $0,079<0,05$, Fasilitas $\left(\mathrm{X}_{3}\right) \mathrm{t}_{\text {hitung }}>\mathrm{t}_{\text {tabel }}$ yaitu $(1,974>1,661)$ dengan tingkat signifikansi $0,051<$ 0,05 dan $\mathrm{t} \quad \alpha 0,05, \quad 96=1,661$ dikarenakan $t_{\text {hitung }}>t_{\text {tabel }}$, maka $\mathrm{H}_{\mathrm{o}}$ ditolak dan $\mathrm{H}_{\mathrm{a}}$ diterima. Hal ini berarti variabel Kualitas Pelayanan $\left(\mathrm{X}_{1}\right)$, Harga $\left(\mathrm{X}_{2}\right)$, Fasilitas $\left(\mathrm{X}_{3}\right)$ berpengaruh positif dan signifikan terhadap kepuasan pelanggan (Y).
Tabel 6. Hasil Perhitungan Uji F

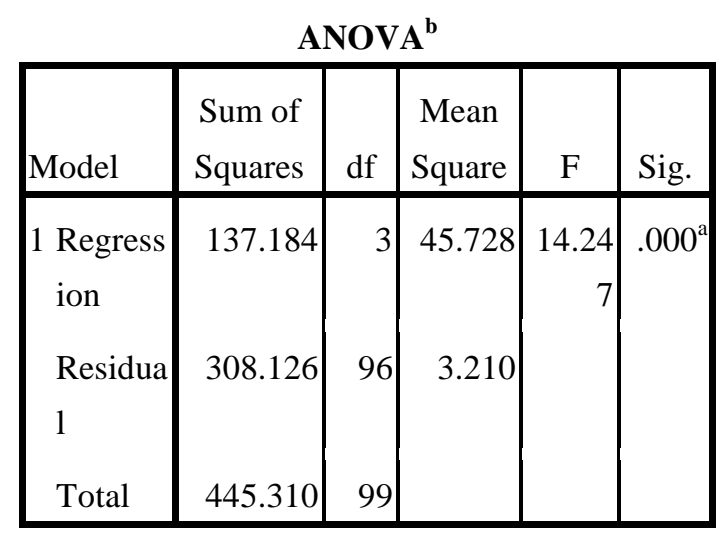

a. Predictors: (Constant), X3, X2, X1

b. Dependent Variable: Y

Dari tabel 6 dan gambar 4 dapt dilihat bahwa nilai $F_{\text {hitung }}$ sebesar 14,247 dengan angka signifikansi ( $P$ value) sebesar 0,000. Dengan tingkat signifikansi $95 \%(\alpha=0,05)$, nilai $\mathrm{F}_{\text {tabel }}$ 3,091. $F_{\text {hitung }} 14,247>F_{\text {tabel }}$ 3,091 dan angka signifikansi ( $\mathrm{P}$ value) sebesar $0,000<0,05$ maka $\mathrm{H}_{\mathrm{o}}$ ditolak dan $\mathrm{H}_{\mathrm{a}}$ diterima atau berarti variabel Kualitas Pelayanan $\left(\mathrm{X}_{1}\right)$, Harga $\left(\mathrm{X}_{2}\right)$ dan Fasilitas $\left(\mathrm{X}_{3}\right)$ mempunyai pengaruh yang signifikan secara bersama-sama (parsial) terhadap variabel Kepuasan Pelanggan (Y).

\section{PEMBAHASAN}

Masyarakat kebanyakan berpikir bahwa rumah sakit yang diharapkan bisa memberikan pelanyanan kesehatan yang mudah, cepat dan murah. Apabila harga yang diberikan oleh pihak rumah sakit mahal maka yang terjadi pelanggan akan mengeluh. Akan tetapi harga yang mahal juga akan memberi harapan pada pelanggan bahwa pelayanan yang diberikan oleh pihak rumah sakit yang akan mereka terima semakin baik. Jika harapan tersebut tidak terpenuhi maka 
pelanggan akan merasa kecewa dan akan menimbulkan keluhan.

Banyak perusahaan penyedia pelayanan jasa kesehatan yang menyadari akan hal tersebut sehingga mereka harus mewujudkan kepuasan pelanggan/pasien tersebut agar pelanggan tidak lari. Rumah sakit bersaing untuk selalu memberikan pelayanan yang berkualitas supaya pelanggan tertarik dan tidak akan berpindah ke rumah sakit lain karena akan merasa puas dengan pelayanan yang telah diberikan rumah sakit tersebut.

\section{KESIMPULAN DAN SARAN}

\section{Kesimpulan}

Berdasarkan pembahasan di atas dapat dikatakan bahwa kualitas pelayanan, harga dan fasilitas secara parsial maupun secara simultan mempengaruhi kepuasan pelanggan. Oleh karena itu para penyedia jasa bersaing untuk memperoleh kepuasan pelanggannya salah satunya dengan terus memberikan pelayananpelayanan yang lebih baik lagi.

\section{Saran}

Meskipun faktor kualitas
pelayanan berpengaruh paling
dominan dalam memberikan kepuasan
pelanggan di RSI Nashrul Ummah
Lamongan, namun rumah sakit
diharapkan dapat memberikan
pelayanan yang lebih baik lagi, harga
yang diberikan harus sesuai dengan
pelayanan dan fasilitas yang diberikan
kepada pasien, untuk meningkatkan
kepuasan pelanggan di RSI Nashrul
Ummah Lamongan juga perlu mempunyai peralatan medis dan non medis yang lengkap, memberikan fasilitas yang nyaman dan memadai serta menjaga kebersihan gedung.

\section{DAFTAR PUSTAKA}

Adisaputro, Gunawan. 2010. Manajemen Pemasaran. Yogyakarta: Sekolah Tinggi Ilmu Manajemen YKPN.

Siregar, Syofian. 2013. Metode Penelitian Kuantitatif. Jakarta: Kencana Prenadamedia Group.

Sugiyono. 2011. Metode Penelitian Kuantitatif Kualitatif dan $R \& D$. Bandung: Alfabeta.

Sugiyono. 2013. Metode Penelitian Kuantitatif Kualitatif dan $R \& D$. Bandung: Alfabeta.

Tjiptono, Fandy. 2004. Manajemen Jasa. Edisi Kedua. Yogyakarta: Andi Offset

Tjiptono, Fandy. 2014. Pemasaran Jasa. Yogyakarta: ANDI 